\title{
Effects of nitrogen deposition on carbon sequestration in Chinese fir forest ecosystems
}

\author{
Xiaohua Wei ${ }^{1,2 *}$, Juan A. Blanco ${ }^{3}$, Hong Jiang ${ }^{4,5^{*}}$ and J.P. (Hamish) Kimmins ${ }^{3}$
}

${ }^{1}$ Department of Earth and Environmental Sciences, University of British Columbia, 3333 University Way, Kelowna, B.C., V1V 1V7, Canada; Tel (+1) 250-807-8750; Fax (+1) 250-807-8005. E-mail: adam.wei@ubc.ca, ${ }^{*}$ Corresponding author.

${ }^{2}$ Adjunct professor with College of Forestry, Jiangxi Agriculture University, Nanchang, Jiangxi province, China, 330045

${ }^{3}$ Department of Forest Science, University of British Columbia, 2424 Main Mall, Vancouver, B.C., V6T 1Z4, Canada; Tel: (+1) 604-822-8876; Fax: (+1) 604-822-9133. E-mail: juan.blanco@ubc.ca, hamish.kimmins@ubc.ca

${ }^{4}$ State Key Laboratory of Subtropical Forest Science \& Zhejiang Provincial Key Laboratory of Carbon Cycling in Forest Ecosystems and Carbon Sequestration, Zhejiang Agriculture and Forestry University, Hangzhou, Zhejiang, China, 311300

${ }^{5}$ International Institute for Earth System Science, Nanjing University, Nanjing, Jiangsu, China, 210093 Tel (+86) 571-63748781; Fax (+86) 571-63740030. E-mail: jianghong_china@ hotmail.com *Corresponding author.

(C) 2012. This manuscript version is made available under the CC-BY-NC-ND 4.0 license http://creativecommons.org/licenses/by-nc-nd/4.0/ 


\begin{abstract}
Nitrogen deposition and its ecologic effects on forest ecosystems have received global attention. In this paper, the ecosystem model FORECAST was used to assess the effects of nitrogen deposition on carbon sequestration in Chinese fir plantation forests. This topic is important as China is intensifying its reforestation efforts to increase forest carbon sequestration for combating climate change impacts, and the Chinese fir is the most important plantation species in China. A series of scenarios including $\mathrm{N}$ deposition levels $\left(1,5,10,20,30,40\right.$ and $50 \mathrm{~kg} \mathrm{ha}^{-1}$ $\mathrm{y}^{-1}$ ), management regime (rotation lengths of 15, 30 and 50 years) and site quality (poor and rich nutrient sites) were defined for the simulations. Our simulation results show that $\mathrm{N}$ deposition increased carbon sequestration in Chinese fir forests, with a higher increasing effect at lower $\mathrm{N}$ deposition levels and lower increasing effect at higher $\mathrm{N}$ deposition levels. When $\mathrm{N}$ deposition levels exceed 20-30 $\mathrm{kg} \mathrm{ha}^{-1} \mathrm{y}^{-1}$, the effects of $\mathrm{N}$ deposition on forest $\mathrm{C}$ pools were marginal; suggesting that $\mathrm{N}$ deposition levels of 20-30 $\mathrm{kg} \mathrm{ha}^{-1} \mathrm{y}^{-1}$ could lead to soil $\mathrm{N}$ saturation in Chinese fir forests. Any additional amounts of $\mathrm{N}$ input from deposition would likely be leached out. It is estimated that the contributions of $\mathrm{N}$ deposition to $\mathrm{C}$ sequestration in the whole Chinese fir forests, South-East China are $7.4 \times 10^{6} \mathrm{Mg} \mathrm{C}$ year ${ }^{-1}$ under the current $\mathrm{N}$ deposition levels (5 to 10 $\mathrm{kg} \mathrm{ha}^{-1} \mathrm{y}^{-1}$ ) and could reach up to $16 \times 10^{6} \mathrm{Mg} \mathrm{C}_{\text {year }}{ }^{-1}$ under hypothetic future $\mathrm{N}$ deposition conditions ( 7.5 to $\left.15 \mathrm{~kg} \mathrm{ha}^{-1} \mathrm{y}^{-1}\right)$.
\end{abstract}

Key words: Nitrogen deposition, carbon sequestration, ecosystem modelling, Chinese fir plantation forests, FORECAST 


\section{Introduction}

Nitrogen is often the most limiting nutrient for tree growth and carbon sequestration (Kimmins and others 2010). There is a growing research interest in the effects of $\mathrm{N}$ deposition on carbon sequestration in forest ecosystems (Fan and Hong 2001; Magnani and others 2007; Thomas and others 2010; Liu and others 2010). Increased N input through deposition can affect forest carbon sequestration in different ways or even opposite directions. On the positive side, $\mathrm{N}$ deposition can increase foliar biomass and photosynthesizing efficiency, and thus increase biomass of forest ecosystems. On the negative side, $\mathrm{N}$ deposition can accelerate nitrogen saturation in areas of high nitrogen in soils, and consequently cause leaching loss of $\mathrm{N}$ and other nutrients (e.g. basic cations) to aquatic systems (Kimmins and others 2010). Interactions of those positive and negative effects determine forest $\mathrm{C}$ sequestration strength. For example, Magnani and others (2007) found that $\mathrm{N}$ deposition plays a critical positive role in forest $\mathrm{C}$ sequestration in boreal and temperate forests. Based on forest inventory data, Thomas and others (2010) showed that the $\mathrm{N}$ deposition with a range of 3 to $11 \mathrm{~kg} \mathrm{ha}^{-1} \mathrm{yr}^{-1}$ increased above-ground biomass by $61 \mathrm{~kg}$ of carbon per kg of $\mathrm{N}$ deposited. However, other evidences showed that increased $\mathrm{N}$ inputs through deposition only added marginal or no effects to forest carbon sequestration (Nadelhoffer and others 1999; De Vries and others 2008). These controversial results suggest that the effects of $\mathrm{N}$ deposition on $\mathrm{C}$ sequestration may be regional or site specific, even though some generalizations can be made. Aber et al. (1998) suggested that net primary production may at first increase with increasing nitrogen deposition, but then decline with nitrogen saturation. Although NPP differs from sequestered $\mathrm{C}$ in accounting for respiration and organic matter decomposition, NPP is the main process to sequester atmospheric $\mathrm{C}$ and therefore increase in sequestered $\mathrm{C}$ with increasing $\mathrm{N}$ deposition rates could be expected. 
Most research on $\mathrm{N}$ deposition focuses on boreal and temperate regions where $\mathrm{N}$ is generally limited, with much less on tropic and sub-tropic regions (Hall and Matson 1999; De Vries and others 2008; Thomas and others 2010). In addition, different tree species may have different responses to $\mathrm{N}$ deposition even in the same region. Thomas and others (2010) found that the effects of $\mathrm{N}$ deposition vary with different tree species. These facts highlights that more research is needed on major different forest species in tropic or sub-tropic regions. Chinese fir (Cunninghamia lanceolata (Lamb.) Hook.) is the most important commercial forest species in subtropical China. It is distributed in 14 provinces of China, with the central area located in Zhejiang, Jiangxi, Hunan and Fujian provinces (Lu and others 2002; Bi and others 2007). Chinese fir has been widely planted in the southeast provinces of China, a region with subtropical climate. The documented history of Chinese fir cultivation can be traced back more than one thousand years (Wu 1984). Traditionally, Chinese fir plantations were established after native evergreen broad-leaved forests were harvested and slash-burned. The plantation sites were generally abandoned after one or two rotations and allowed to regenerate naturally by stump sprouting and natural seeding to mixed species stands, which then acted as a fallow period to restore the site (Yu 1997). However, since the 1950s, the plantation area of Chinese fir has been enlarged, and this species has been repeatedly planted on the same sites without intercropping or periods of fallow. Forest farmers have generally used a 25-year rotation, with variation from 20 to 30 years depending on site quality (i.e., nutrient abundance, Wu 1984), a trend driven by the increasing demand for timber caused by economic development and population increase. Continuous cultivation of Chinese fir at the same site has resulted in a well known ecological problem: yield decline over consecutive rotations (Yu 1988; Sheng and Xue 1992). Among various possible reasons, $\mathrm{N}$-limitation is the most important factor responsible for yield decline 
(Li and others 1993). Nitrogen limitation is the result of nutrient losses caused by timber harvest, post-harvest slash burning and soil erosion in the Chinese fir forests (Bi and others 2007).

Rapid industrial development has caused the sub-tropical region of China to become one of the major $\mathrm{N}$ deposition areas in the world (Richter and others 2005). The impacts of $\mathrm{N}$ deposition on forest carbon sequestration capacity in Chinese fir plantation forests in the sub-tropical region of China are poorly understood. Several models have been used to assess the effect of $\mathrm{N}$ deposition on carbon sequestration. Globally, Jain and others (2009) showed the historical enhancement of global $\mathrm{C}$ sinks by $\mathrm{N}$ dynamics with the ISAM model, which could be especially intense in secondary forests (Yang and others 2010). Townsend and others (1996) used a perturbation model of biogeochemistry (NDEP) and estimated terrestrial carbon storage increase arising from nitrogen deposition. Similar results were reported by Zahele and other (2010) using the O-CN model. Regionally, Ollinger and others (2002) using the model PnET-CN found that N deposition could have significantly increased tree growth in north-eastern USA. Churkina and others (2007), using the BIOME-BGC model, showed that $\mathrm{N}$ deposition could significantly increase sequestered C but only in secondary forests. Applying the Generic Decomposition and Yield forest C-N cycling model (G'DAY), Dezi and others (2010) estimated that the C storage capacity of a generic European forest ecosystem was at the most $121 \mathrm{~kg} \mathrm{C} \mathrm{kg}^{-1} \mathrm{~N}$ deposited. In China, Tian and others (2011) estimated with the TEM model increases in C sequestration under $\mathrm{N}$ deposition, but with regional variations. Zhao and others (2010) used the GEMS model to estimate increases in C pools along the Yangtze River. Wang and others (2007) also detected the increase in $\mathrm{C}$ sink strength in the latest decades using the InTEC model, an estimation also described by Fang and others (2001). 
The studies mentioned before have some common features: they are of regional to global in scale; they do not simulate individual species but broad functional groups (i.e. deciduous, conifers, etc); and they do not explicitly simulate forest management. Therefore, they are not well suited to study the interactions between $\mathrm{N}$ deposition and forest management, which are dependent on local factors such as species composition or nutrient. As a consequence, an ecosystem-level forest management model is more suitable (Kimmins and other 2008). The model FORECAST has been used as a management evaluation tool in many types of world forest ecosystems (Sachs and Sollins 1986; Wang and others 1995; Morris and others 1997; Wei and others 2000, 2003; Blanco and others 2007; Bi and others 2007; Seely and others 2010; Blanco and González 2010a, b). The model was specially designed to examine the impacts of different management strategies or natural disturbance regimes on long-term site productivity and forest carbon sequestration. A detailed description of the FORECAST model can be found in Kimmins and others 1999, 2010) and a brief description of the algorithms simulating C sequestration and $\mathrm{N}$ limitation will be presented in the next section.

The objective of this paper was to evaluate the effects of various levels of $\mathrm{N}$ deposition on $\mathrm{C}$ sequestration capacity in Chinese fir planted forests. This evaluation was conducted in conjunction with various forest management scenarios (e.g., rotation length, site quality). Our ultimate goal is to understand the potential of a major sub-tropic plantation species for storing $\mathrm{C}$ with various levels of $\mathrm{N}$ deposition using Chinese fir forests as a study case. The reason of choosing Chinese fir forests are: 1) N-limitation is a common problem in secondary forests of the sub-tropical region, usually as a result of unsustainable forest practices in the past, causing longterm yield decline ( $\mathrm{Li}$ and others 1993, LeBauer and Treseder 2008); 2) Chinese fir forest is perhaps the most studied forest in the sub-tropics, suggesting sufficient existing data exist for 
calibrating the FORECAST model; and 3) there are large spatial variations in $\mathrm{N}$ deposition in Chinese fir forests resulting from various levels of industrial development in southern China (Figure 1). All those reasons indicate an excellent opportunity to use Chinese fir as a case study to assess the response of forest ecosystems to $\mathrm{N}$ deposition in subtropical forests.

[Figure 1 here]

\section{Material and Methods}

\section{Chinese fir forest ecosystems}

The natural range of Chinese fir (Cunninghamia lanceolata (Lamb.) Hook.), a typical subtropical coniferous tree species, is in the humid subtropical area in southeast China, a region of approximately 22 to $34^{\circ} \mathrm{N}$ and 102 to $123^{\circ} \mathrm{E}$ (Wu 1984; Yu 1997) (Figure 1). This is a region of low mountains and hills, with very broken topography and complicated geology. The natural distribution of Chinese fir is as a component of mixed subtropical evergreen broad-leaved forests. Plantations are generally located on slopes of more than $20 \%$, gentler lower slopes generally being used for agriculture ( $\mathrm{Bi}$ and others 2007). The soil type is usually red-earth, but the soil can be originated from very different parent materials. The soil conditions vary significantly in terms of texture, depth, fertility and other physical and chemical characteristics. It is a species of moderate shade tolerance, but it grows best in full sunlight (Wu 1984; Yu 1997). The species is moderately nutrient demanding (Zhong and Hsuing 1993), and in unmanaged "natural" forests it normally grows on moist and fertile sites. The response of Chinese fir to forest fertilization varies with stand age. Growing on yellow-red earth soils, the greatest growth response of young Chinese fir is reported to be to $\mathrm{P}$ and $\mathrm{K}$ fertilization, while growth in mid and late rotation responds mostly to $\mathrm{N}(\mathrm{Li}$ and others $1992 a, b ; 1993)$. 
Chinese fir is one of the most important timber tree species in China, accounting for $60-80 \%$ of the total area of timber plantations in southeast China, and for $20-25 \%$ of the national commercial timber output (Sheng 1992; Lu and others 2002). The timber of Chinese fir is straight and decay-resistant, and has a long history of being an important construction and furniture material in China. It is the most important fast-growing timber tree of the warm regions south of the Chang Jiang valley (Wu and Raven 1999). It can reach a level of timber production in monoculture plantations on good sites of $150 \mathrm{~m}^{3} \mathrm{ha}^{-1}$ at age 10 year and $450 \mathrm{~m}^{3} \mathrm{ha}^{-1}$ at final harvest age of 25-30 years (Lu and others 2002). However, the productivity in many areas is not great because of fertility loss by long-term overexploitation (Lu and others 2002; Bi and others 2007). In spite of this fact, there has been a steady increase in its use in plantations in the past few decades.

\section{FORECAST model description}

FORECAST is a hybrid model that uses empirical and mechanistic relationships. The model is used in a two-stage sequence (see Supplementary Material for a description of model use and calibration). During the calibration stage, the model uses historical field data to estimate realized rates of tree growth and other ecological processes. Then, during the simulation stage, FORECAST simulates the ecological processes that control tree growth in a mechanistic way, estimating resource availability and its impacts on different $\mathrm{C}$ pools in the ecosystem. The model has an annual time step and provides estimates of a wide range of ecological variables at annual intervals, but because our objective is to study the long-term changes and the interactions between forest management, site quality and $\mathrm{N}$ deposition rates, we display here only the end-ofrotation or rotation-average values (see Results). A general description and a model diagram can 
be found in the Supplementary Material, whereas a detailed description of FORECAST can be found in Kimmins and others (1999). The particular processes related to C sequestration are described below.

During the calibration stage, for each plant species for which historical data are provided, the total net primary production (TNPP) that occurred for each annual time step $(t)$ is calculated with Equation (1).

$\mathrm{TNPP}_{\mathrm{t}}=\Delta$ biomass $_{\mathrm{t}}+$ litterfall $_{\mathrm{t}}+$ mortality $_{\mathrm{t}}$

where $\Delta$ biomass $_{\mathrm{t}}=$ the sum of the change in mass of all the biomass components of the particular species in time step $t$; litterfall $\mathrm{t}_{\mathrm{t}}=$ the sum of the mass of all ephemeral tissues that are lost in time step $t$ (e.g., leaf, branch, bark and reproductive litterfall, and root death); and mortality ${ }_{\mathrm{t}}=$ the mass of individual plants that die in time step $t$. Change in biomass $\left(\Delta\right.$ biomass $\left._{t}\right)$ in each time step is derived from a series of age-biomass curves created with empirical data. Litterfall is calculated based on user-defined litterfall rates. Mortality is derived from a series of age-stand density curves created with empirical data (see Kimmins and others 1999, for a detailed description on mortality simulation in FORECAST).

The model also estimates the shade-corrected foliage N content (SCFN), which represents the amount of fully illuminated foliage $\mathrm{N}$ that would be required to produce the calculated TNPP. To estimate foliage shading, FORECAST simulates canopy foliage biomass as a "blanket" that covers the stand and that is divided in several layers of $0.25 \mathrm{~m}$ height, each of them increasingly darker from the top of the canopy to the bottom. The light absorbed by each layer is calculated based on the foliage biomass present in that time step and a user-defined empirical curve of foliage mass-proportion of full light. Once an estimation of self-shading has been completed for 
a particular time step using the canopy representation method described above, FORECAST calculates a foliar $\mathrm{N}$ content value adjusted for the effects of self-shading (Equation 2).

$S C F N_{t}=\sum_{i=1}^{n}\left(F N_{t, i} \times P L S C_{i}\right)$

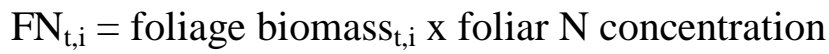

where $\mathrm{FN}_{\mathrm{t}, \mathrm{i}}=$ mass of foliage nitrogen in the $i$ th quarter-meter height increment in the live canopy at time $t$, PLSC $_{\mathrm{i}}=$ photosynthetic light saturation curve value for the associated light level in the $i$ th quarter-meter height increment in the live canopy, $\mathrm{n}=$ number of quarter-meter height increments in the live canopy at time $t$. The mean photosynthetic rate of the foliage in canopy level $i$ is calculated by combining simulated light intensities in canopy level $i$ with input data that define photosynthetic light saturation curves for the foliage type in question. The driving function curve for potential growth of a given species in FORECAST is the shadecorrected foliar nitrogen efficiency (SCFNE) calculated for each annual time step $(t)$ as: $\mathrm{SCFNE}_{\mathrm{t}}=\mathrm{TNPP}_{\mathrm{t}} / \mathrm{SCFN}_{\mathrm{t}}$

When data describing the growth of a species on more than one site quality are provided, SCNFE function curves will be generated during the calibration stage for each site quality.

During the simulation stage, annual potential growth (APG) of vegetation in FORECAST is driven by the photosynthetic production of the foliage biomass (Equation 5). The productive capacity of a given quantity of foliage biomass (photosynthetic rate) is assumed to be dependent on foliage nitrogen content corrected for shading created by the canopy of the simulated site $\left(\mathrm{SCFN}_{\mathrm{t}}{ }^{*}\right) . \mathrm{SCFN}_{\mathrm{t}}{ }^{*}$ is different from the $\mathrm{SCFN}_{\mathrm{t}}$ that was previously calculated during the calibration stage. During the simulation stage the canopy simulated corresponds to the site defined by the user for that particular scenario, which can be different from the empirical canopy data used during the calibration stage, and therefore $\mathrm{SCFN}_{\mathrm{t}}{ }^{*}$ is particular for each simulation. 
$\mathrm{APG}_{(\mathrm{t}+1)}=\mathrm{SCFN}_{\mathrm{t}} * \mathrm{x} \mathrm{SCFNE}_{\mathrm{t}}$

where: $\mathrm{APG}_{(\mathrm{t}+1)}=$ annual potential growth for a given species in the next time step. During the simulation stage, the model interpolates between the different curves of SCFNE calculated before to find the site quality of the simulated site (see Supplementary Material).

While the annual potential growth (APG) of vegetation in FORECAST is determined as a function of SCFNE, the actual annual growth (AAG) achieved in a given annual time step depends upon whether the nutrient uptake demand created by this potential growth can be satisfied by the available nutrient resources. The quantity of available nutrient resources in a given time step is a function of: (a) the simulated internal translocation of nutrients within the plants (based on user-defined data on nutrient concentration and specific gravity changes with tissue death); (b) simulated net canopy uptake and leaching losses; and (c) the simulated level of available nutrients in the soil that is accessible to the plants. Nutrient cycling in FORECAST is based on a mass balance approach where nutrients can exist in three distinct pools: (1) The plant biomass pool; (2) the available soil nutrient pool; and (3) the soil organic matter and forest floor pool (see Figure S1). The storage of nutrients in the available soil nutrient pool from one time step to the next is limited by the nutrient-specific ion exchange capacities defined by the user. The size of these exchange capacities (cation exchange capacity [CEC] or anion exchange capacity $[\mathrm{AEC}])$ can be defined to change as a function of site quality.

Inputs and outputs of nutrients to the ecosystem are simulated in a mass-balance four-stage process for each annual time step. First, geochemical inputs are calculated: mineral weathering, seepage, atmospheric deposition, or fertilization. For all these fluxes, all the forms of $\mathrm{N}$ are lumped together. Second, the biochemical $\mathrm{N}$ fluxes are considered: volatilization, immobilization 
of $\mathrm{N}$ in litter, symbiotic and asymbiotic $\mathrm{N}$ fixation. Third, any amount of $\mathrm{N}$ remaining at this point is considered "available N". Therefore, available $\mathrm{N}$ in FORECAST can be assimilated to the amount of $\mathrm{N}$ made available in a year in the soil solution in any form together with the labile organic $\mathrm{N}$ with turnover rates shorter than one year. This $\mathrm{N}$ is available for plant uptake at this point. Fourth, the available $\mathrm{N}$ remaining in soil for the next time step is calculated by dividing the total $\mathrm{N}$ into the soil $\mathrm{CEC}$ or AEC pools using a user-defined nitrate/ammonium ratio. Any nutrients remaining in the available nutrient pool in excess of the defined ion exchange capacities of a site are assumed to be lost from the ecosystem via leaching. Leaching of nitrate- $\mathrm{N}$ is more accurately defined as the 'disappearance' of nitrate- $\mathrm{N}$ because the model does not explicitly simulate the process of microbial denitrification. Loss of soil nitrate is assumed to represent the combination of both leaching and denitrification. Most of the simulated leaching in FORECAST is assumed to be of nitrate-N rather than ammonium- $\mathrm{N}$ because the simulated soils normally have a higher CEC than AEC. The failure to deal explicitly with denitrification, which can be a major source of post-harvest N loss in some types of forest (Davidson and others 1990; Struwe and Kjøller 1990), is a limitation of FORECAST's representation of the geochemical cycle.

Competition for nutrient resources among simulated plant species is represented in FORECAST as a function of simulated annual nutrient uptake demand, the size of the available nutrient pool, and the relative occupancy of the soil by fine roots of each species. The annual $\mathrm{N}$ uptake demand for a given species is determined using a mass balance approach driven by the potential growth in which the nutrient demands to meet potential growth are calculated while accounting for internal cycling, canopy uptake and foliar leaching. If there is no enough available $\mathrm{N}$ to cover all the nutrient demands from the simulated species, the available $\mathrm{N}$ is distributed among the plant species based on their fine-root biomass and soil root occupancy. As a consequence, AAG will 
be less than APG, and the site quality is assumed to have worsened during that time step. The opposite situation could also occur: any excess of available $\mathrm{N}$ could be used to produce AAG higher than APG, reflecting an improvement in site quality.

\section{Simulation of atmospheric $\mathrm{N}$ deposition regimes}

Simulations were carried out for two different sites: a poor site (dominant tree height or Site Index [SI] $18 \mathrm{~m}$ at year 50) and a rich site (SI $26 \mathrm{~m}$ at year 50). The initial conditions for each site are presented in Table 1. In both sites the following regimes of $\mathrm{N}$ deposition were simulated: $1,5,10,20,30,40$ and $50 \mathrm{~kg} \mathrm{ha}^{-1} \mathrm{y}^{-1}$. These levels are based on reported depositions in southeast China (Figure 1). A level of $1 \mathrm{~kg} \mathrm{ha}^{-1} \mathrm{y}^{-1}$ corresponds to natural areas with no influence of pollution centers (Lian and Zhang 1998), whereas $5 \mathrm{~kg} \mathrm{ha}^{-1} \mathrm{y}^{-1}$ is the average deposition in areas with human population without industrial development (Li 1996; Chen and Mulden 2007; Ma and others 2007). Levels ranging from 7 to $50 \mathrm{~kg} \mathrm{ha}^{-1} \mathrm{y}^{-1}$ have been reported in polluted areas in south-east China, with values around $30 \mathrm{ha}^{-1} \mathrm{y}^{-1}$ being the most common, but reaching up to 73 $\mathrm{ha}^{-1} \mathrm{y}^{-1}$ in the proximity of large industrialized urban areas such as Shanghai (Chen and others 2004; Chen and Mulder 2007; Fang and others 2007; Lu and others 2008).

We did not use scenarios with much higher levels of $\mathrm{N}$ deposition (e.g., 80 or $100 \mathrm{~kg} \mathrm{ha}^{-1} \mathrm{y}^{-1}$ ) for this simulation study as these high levels (or toxic levels in question) may potentially cause negative effects on forest growth that the current version of FORECAST model does not have the capability to deal with. However, we believe that our defined scenarios are suitable, as they are not at toxic levels for the following reasons. First, the studied forest ecosystems are generally $\mathrm{N}$ limited because of long term mismanagement (slash burning, application of short rotations etc.; Li and others 1993, LeBauer and Treseder 2008). Secondly, no negative effects on tree 
growth in Chinese fir forest ecosystems have been reported yet despite occurrence of some high $\mathrm{N}$ deposition levels (73 $\mathrm{kg} \mathrm{ha}^{-1} \mathrm{y}^{-1}$ was the highest level documented to date). Finally, the experimental study from Mo and others (2008) found that addition of $\mathrm{N}\left(50-100 \mathrm{~kg} \mathrm{ha}^{-1} \mathrm{y}^{-1}\right)$ still significantly increased seedling growth of two tropical forests (Schima superba and Cryptocarya concinna), but the higher amounts caused negative effects (soil acidification and nutrient imbalance) and therefore reducing root growth. Other studies on the subtropical evergreen broad-leaved old-growth forests in south-eastern China have documented decline on forest biomass (Zhang and others 2002) and a decreasing trend on litter production (Guan and others 2004). However, whether increased $\mathrm{N}$ depositions in the region were responsible for those declines has not been concluded (Fang and others 2008).

\section{Results}

\section{Effects of $\mathrm{N}$ deposition on $\mathrm{C}$ sequestration}

A detailed model evaluation showed an acceptable model performance for simulating several stand-level variables at these sites (see Supplementary Material). There was a general pattern of long-term decreasing in amounts of $\mathrm{C}$ in different ecosystem pools in both sites at low levels (1 and $5 \mathrm{~kg} \mathrm{~N} \mathrm{ha}^{-1} \mathrm{y}^{-1}$ ) of nitrogen deposition (Table 2). These trends changed for most of the variables at the input levels of 10 and $20 \mathrm{~kg} \mathrm{~N} \mathrm{ha}^{-1} \mathrm{y}^{-1}$, and showed greater magnitudes and increasing trends for both the poor and rich sites, respectively, particularly for longer rotation lengths. When the input levels were greater than $20 \mathrm{~kg} \mathrm{~N} \mathrm{ha}^{-1} \mathrm{y}^{-1}$, all C variables had greater amounts and increasing trends regardless of rotation lengths. These results suggest that the $\mathrm{N}$ deposition levels defined in this study play positive effects on different forest $\mathrm{C}$ pools.

[Table 2 here] 
Figure 2 shows that total aboveground C (which includes tree and understory C) was more sensitive to rotation length than to site quality, but it was $\mathrm{N}$ deposition that created the greatest differences among scenarios, changing from patterns of decreasing $\mathrm{C}$ accumulation when there were less than $10 \mathrm{~kg} \mathrm{ha}^{-1} \mathrm{y}^{-1}$ (poor site, 15 -year rotation; rich site, 15 and 30-year rotations) to increasing $\mathrm{C}$ accumulation for higher deposition scenarios, reaching a maximum after 2-3 rotations. For the 50-year rotation length, just $5 \mathrm{~kg} \mathrm{~N} \mathrm{ha}^{-1} \mathrm{y}^{-1}$ were needed to increase $\mathrm{C}$ accumulation at both sites. Clearly, total above-ground $\mathrm{C}$ was more sensitive to $\mathrm{N}$ deposition than to rotation length and site quality.

[Figures 2 and 3 here]

When soil $\mathrm{C}$ was included in the analysis to account for total ecosystem $\mathrm{C}$, site quality became a more important factor determining $\mathrm{C}$ storage (Figure 3). The difference between sites remained consistent for all the scenarios, with the rich site doubling the amount of $\mathrm{C}$ accumulated at the end of each rotation. Figure 3 also shows that the higher the $\mathrm{N}$ deposition the higher the amount of ecosystem $\mathrm{C}$, but the differences among the high deposition scenarios were reduced as the rotation length increased. The results for $\mathrm{N}$ deposition inputs of 40 and $50 \mathrm{~kg} \mathrm{ha}^{-1} \mathrm{y}^{-1}$ were almost identical and very similar to the ones for $30 \mathrm{~kg} \mathrm{ha}^{-1} \mathrm{y}^{-1}$. This demonstrates that the effects of additional $\mathrm{N}$ deposition on forest $\mathrm{C}$ pools were marginal when $\mathrm{N}$ deposition levels exceed $30 \mathrm{~kg}$ $\mathrm{ha}^{-1} \mathrm{y}^{-1}$.

The carbon sequestration efficiency of deposited $\mathrm{N}$ can be defined as the amount of $\mathrm{C}$ accumulated in the ecosystem divided between the amount of $\mathrm{N}$ deposited in that ecosystem. This ratio dropped quickly at both sites as the deposition levels increased and also when rotation length was extended (Figure 4). The lowest deposition level had the highest $\mathrm{C}$ accumulation 
efficiency at both sites, but this efficiency also dropped over time, with the decrease being steeper at the rich site.

\section{[Figures 4 and 5 here]}

Leached $\mathrm{N}$ from the sites was in direct relationship to the deposited $\mathrm{N}$, although at the lowest deposition level it was actually higher than the total deposited $\mathrm{N}$ (Figure 5). The more $\mathrm{N}$ deposition, the greater leaching loss. The cumulative retained $\mathrm{N}$ increased with $\mathrm{N}$ deposition up to 20 to $30 \mathrm{~kg} \mathrm{~N} \mathrm{ha}^{-1} \mathrm{y}^{-1}$, and then the accumulated retained $\mathrm{N}$ stabilised at both sites, sooner with longer rotations. Figure 5 also shows that either leached $\mathrm{N}$ or retained $\mathrm{N}$ were much more sensitive to rotation lengths than to site quality. The difference in leached $\mathrm{N}$ or retained between poor and rich sites was relatively small, as the poor site quickly reached a $\mathrm{N}$ availability similar to the one at the rich site (see Supplementary Material Figures).

\section{Importance of $\mathrm{N}$ deposition in the regional forest $\mathrm{C}$ storage in South-East China} Under current deposition levels, most of the area occupied by Chinese fir plantation forests in south-east China is under 5 to $10 \mathrm{~kg} \mathrm{~N} \mathrm{ha}^{-1} \mathrm{y}^{-1}$ with a few areas receiving 10 to $20 \mathrm{~kg} \mathrm{~N} \mathrm{ha}^{-1} \mathrm{y}^{-1}$ (Figure 1). This accounts potentially for a total of $2.5 \times 10^{6} \mathrm{Mg} \mathrm{C}$ sequestered annually in the aboveground of Chinese fir plantations, and up to $7.4 \times 10^{6} \mathrm{Mg} \mathrm{C}_{\text {year }}{ }^{-1}$ in total ecosystem $\mathrm{C}$ caused by anthropogenic $\mathrm{N}$ deposition (Table 3). Assuming that $\mathrm{N}$ deposition rates will likely keep increasing (Liu and others 2010) and that most of the Chinese fir area could move from current average levels of $7.5 \mathrm{~kg} \mathrm{~N} \mathrm{ha}^{-1} \mathrm{y}^{-1}$ to $15.0 \mathrm{~kg} \mathrm{~N} \mathrm{ha}^{-1} \mathrm{y}^{-1}$, the increase in $\mathrm{C}$ sequestration in Chinese fir forests could reach $16 \times 10^{6} \mathrm{Mg} \mathrm{C}$ year $^{-1}$.

[Table 3 here] 


\section{Discussion}

\section{Effects of $\mathrm{N}$ deposition on $\mathrm{C}$ sequestration}

Impacts of various $N$ deposition levels on carbon sequestration

Medium to high levels of nitrogen deposition increase $\mathrm{C}$ sequestration in Chinese fir forests through supporting higher plant growth and biomass production. Soil $\mathrm{C}$ also increases as the mass of humus and decomposing litter increases, as has been observed in the field (Berg and Matzner 1997; Fang and others 2007). This should assist in the recovery of productivity and carbon storage in subtropical degraded forests in China (Mo and others 2006). It has been reported that almost half of the $\mathrm{C}$ in Chinese fir forests is in the upper $30 \mathrm{~cm}$ of soil, a layer that is easily altered by management (Fu and others 2006). An increase in this superficial reservoir of organic matter results in increased $\mathrm{N}$ availability for plants, which is especially important in this region where $\mathrm{N}$ is the limiting factor for tree growth (Fan and Hong 2001; Wang and others 2005) and where soils usually have lower $\mathrm{N}$ contents than those in temperate regions (Chen and Mulder 2007). However, $\mathrm{N}$ deposition rates higher than $20-30 \mathrm{~kg} \mathrm{ha}^{-1} \mathrm{y}^{-1}$ are not predicted to provide additional gains, suggesting that the soils of this region could quickly reach $\mathrm{N}$ saturation, and that further $\mathrm{N}$ additions will produce only marginal increases in tree growth. This conclusion is in agreement with previous research on these forests, which have reported ecosystem saturation at deposition levels above $25 \mathrm{~kg} \mathrm{~N} \mathrm{ha}^{-1} \mathrm{y}^{-1}$ (Mo and others 2006; Fang and others 2008). The incremental gains in NPP became smaller as the N deposition levels increased (see Supplementary Material Figures), which follows Aber and other's (1998) hypothesis of initial increases in NPP with increasing $\mathrm{N}$ availability up but only until they reach a peak when the ecosystem gets saturated, declining after that. 
Our modelling exercise predicts that low $\mathrm{N}$ deposition rates will not maintain the long term productivity of these Chinese fir forests under contemporary management regimes. At these sites, the ecosystem capacity to store carbon is depleted over time largely as a result of the reduction in soil organic matter and associated nutrients. Humus is the main nutrient reservoir in these soils, and intensive harvesting in such forests as represented in our scenarios will inevitably produce depletion of nutrient reserves and site quality degradation (see Supplementary Material Figures). Although $\mathrm{N}$ use efficiency is expected to increase as trees adapt to decreasing site qualities, this adaptation will not be sufficient to sustain tree growth unless $\mathrm{N}$ lost by harvesting is replaced through fertilization.

Our projections also indicate that increasing $\mathrm{N}$ deposition rates may have initial positive effects in terms of increasing the amount of $\mathrm{C}$ stored in these forests, and therefore counteracting some of the reductions on $\mathrm{C}$ storage capacity observed after the conversion of natural forests into short rotation conifer plantations (Huang and others 2004; Chen and others 2005). These positive effects, however, could be quickly overshadowed by the negative effects of increased leaching losses projected for the high-deposition-rate scenarios that could potentially reach aquatic systems, and reduction and alteration of various measures of forest biodiversity ( $\mathrm{Lu}$ and others 2008; Liu and others 2010).

\section{Impacts of $N$ deposition on leaching losses and efficiency of $N$ addition}

Deposition of atmospheric $\mathrm{N}$ has direct implications for $\mathrm{N}$ leaching rates. Whereas at low deposition rates (10 $\mathrm{kg} \mathrm{N} \mathrm{ha}^{-1} \mathrm{y}^{-1}$ or less) leaching losses are minimum and decrease over time, there is a clear switch at atmospheric inputs of $20-30 \mathrm{~kg} \mathrm{~N} \mathrm{ha}^{-1} \mathrm{y}^{-1}$, and any higher deposition rate will produce increasing leaching losses over time. This is a direct result of the ecosystem 
reaching the $\mathrm{N}$ saturation point, after which any additional $\mathrm{N}$ will be leached away. This prediction is in agreement with experimental data from Chinese fir forests (Chen and others 2004; Fang and others 2008, 2009). Our results also indicate that $\mathrm{N}$ retention is largely determined by the levels of $\mathrm{N}$ deposition. Although at low levels the $\mathrm{N}$ retained can be a large fraction of the $\mathrm{N}$ deposited, there is a threshold marking the $\mathrm{N}$ saturation state, and from this point no more $\mathrm{N}$ is retained in the forests. This threshold appears to be about $20-30 \mathrm{~kg} \mathrm{~N} \mathrm{ha}^{-1} \mathrm{y}^{-1}$ depending on site quality, but it can be increased if trees are harvested at more frequent periods (shorter rotations), which have higher amounts of N removed by harvesting. Similar effects have been described before for Chinese sub-tropical forests (Fang and others 2009).

As a consequence of $\mathrm{N}$ saturation, $\mathrm{N}$ deposition efficiency (the amount of biomass that can be produced per unit of deposited N) drops rapidly as deposition rates increase. This indicates that although these forests could benefit from moderate increases from atmospheric $\mathrm{N}$ deposition rates under intensive harvesting (e.g., extracting the whole tree and not just the stems), the capacity of trees to take advantage of this additional nutrient source is quickly saturated at medium deposition levels. Any additional increase in atmospheric $\mathrm{N}$ inputs will translate in increases in leached N. Such leached N can cause increases in algae growth, eutrophication and other effects that may be undesirable in N-limited aquatic systems (Matson and others 2002; Chen and others 2004; Liu and others 2010). Some of these effects in the streams of the region have already being reported (Fang and others 2009; Liu and others 2010).

Site quality impacts on the $N$-deposition and carbon relationship.

Site quality (e.g., nutrient abundance) is an important factor in the capacity of Chinese fir forests to store carbon. The higher the site quality, the higher the accumulated $\mathrm{C}$ in the system, mainly 
because of the higher accumulation of organic matter in the soil created by higher inputs of litter from canopies with higher foliage mass. However, the difference between sites quickly disappears under scenarios of medium to high $\mathrm{N}$ deposition. The accumulation of $\mathrm{N}$ in the soil under these circumstances creates a rapid increase in site quality at the poor site, and after only two or three rotations the poor site reaches a site quality equivalent to the rich site (assuming that site quality is mainly related to nutritional status and not to soil moisture status). This increase ceases after the ecosystem reaches its $\mathrm{N}$ saturation point, and as a result the maximum site quality at both sites, reached when $\mathrm{N}$ deposition rates are $10 \mathrm{~kg} \mathrm{~N} \mathrm{ha}^{-1} \mathrm{y}^{-1}$ or more, is about $28 \mathrm{~m}$ of dominant tree height at year 50. This is only marginally higher than the site quality at the rich site at the beginning of the simulation $(26 \mathrm{~m})$, and therefore poor sites will benefit much more from increasing $\mathrm{N}$ deposition rates than rich sites. Similar results have been reported from field research in disturbed Chinese forests (Mo and others 2003)

\section{Rotation impacts on the $\mathrm{N}$-deposition and carbon relationship.}

Rotation length (i.e. the time needed to harvest the plantation) is an important factor affecting the $\mathrm{N}$-deposition/C-accumulation relationship at low $\mathrm{N}$ deposition rates, but its importance decreases as $\mathrm{N}$ deposition increases. This is a direct consequence of the reduction of $\mathrm{N}$ limitation under medium to high deposition scenarios, where the inputs of $\mathrm{N}$ surpass losses from the ecosystem in harvested material and by leaching. Short rotation and intensive forestry in the past has been linked to reductions of productivity and even total failure of Chinese fir plantations (Zhang and others 2004; Bi and others 2007; Ma and others 2007), but our projections indicate that in areas with medium to high levels of atmospheric $\mathrm{N}$ inputs, this problem will likely be reduced. While very short rotations can potentially cause a long-term reduction in the ecosystem capacity to store $\mathrm{C}$ (especially on initially nutritionally-poor sites), this effect is reduced under higher 
atmospheric $\mathrm{N}$ deposition. However, reaching or passing the $\mathrm{N}$ saturation point in the system will likely produce another set of environmental problems.

\section{Significance of $\mathrm{N}$ deposition on the regional forest $\mathrm{C}$ storage}

Our result show the potentially important increases in $\mathrm{C}$ stored in Chinese fir forests caused by $\mathrm{N}$ deposition, with up to 7 million tonnes per year currently, which could more than double if $\mathrm{N}$ deposition rates keep increasing as it is expected (Liu and others 2010). Based on our estimations Chinese fir plantations account currently for $10.8 \%$ of the C stored annually in SE China and $4.3 \%$ in all China (Piao and others 2009), and for $35.2 \%$ of the C stored annually by planted forests in all China (Fang and others 2001). This provides an idea of the importance of this species for $\mathrm{C}$ sequestration at regional and national levels. However, it should be noticed that we have not accounted for $\mathrm{C}$ being released in planting, logging and transportation operations, neither from decomposing harvested products. As a result, the net gains in $\mathrm{C}$ sequestered in Chinese fir plantations would be lower than the potential values presented here. Our results support previous findings by Churkina and others (2007) and Yang and others (2010), who stated that $\mathrm{N}$ deposition could significantly increase $\mathrm{C}$ sequestration in secondary forests, which are usually N limited even in tropical or sub-tropical areas (Lebauer and Treseder 2008).

However, our estimations are based on the simulation of available $\mathrm{N}$ as the major growth limiting factor. Increases in $\mathrm{N}$ availability without concomitant additions of other limiting nutrients to maintain nutrient ratios within physiologically-acceptable limits can lead to reductions in tree growth. For example, the continuous input of $\mathrm{N}$ could reduce the role of $\mathrm{N}$ as a limiting factor of tree growth and therefore making other nutrients such $\mathrm{P}$ as the limiting factor (Braun and others 2010). This phenomenon has not been reported for Chinese fir forests yet, and 
it is not appreciable in our simulations, but it may deserve additional consideration in future research as it could cause reduced growth response to $\mathrm{N}$ deposition. In addition, $\mathrm{N}$ deposition can be accompanied by acid rains in the vicinity of pollution centers. Under continuous acid rains a drop in soil $\mathrm{pH}$ has been reported, producing a mobilization of $\mathrm{Al}^{3+}$ that displaces other cations from the soil solution, and therefore increasing their leaching losses and reducing CEC (Smith 1990; Ulrich 1991). Because of its toxicity, $\mathrm{Al}^{3+}$ can also reduce decomposition and affect root growth, increasing nutrient limitation for trees (Mulder and others 2001). However, most of this region experiences moderate acid rain pHs of 4.5 - 5.0 (Larssen and others 2006), and in a parallel study we have found that $\mathrm{N}$ deposition levels of $7.5 \mathrm{~kg} \mathrm{~N} \mathrm{ha}^{-1} \mathrm{y}^{-1}$ and above can counteract most of the negative effects of acid rain on tree growth (Blanco et al., in preparation). All things considered, our results show the high potential of $\mathrm{N}$ deposition for altering the $\mathrm{C}$ budgets in south-eastern China through increasing forest and soil biomass in Chinese fir plantations (an area of $\sim 70,000 \mathrm{~km}^{2}$ ). Although the limitations of our approach indicated before mean that the actual $\mathrm{C}$ change caused by $\mathrm{N}$ deposition is likely lower than the potential calculated here, the change in $\mathrm{C}$ budgets could be even bigger if other forests types such as Masson pine, bamboo plantations or natural mixedwoods experience similar $\mathrm{C}$ gains to the ones described here for Chinese fir forests.

Multiple environmental factors can affect forest carbon sequestration capacity (Tian and others 2011). Using a modeling approach, Tian and others (2011) evaluated relative contributions of various environmental factors (climate, atmospheric $\mathrm{CO}_{2}$, ozone pollution, nitrogen deposition, nitrogen fertilizer application and land cover/land use change) to net carbon balance in terrestrial ecosystems of China for the period of 1961-2005, and identified nitrogen inputs ( $\mathrm{N}$ deposition and $\mathrm{N}$ fertilizer application) as primary driver of carbon sequestration. Our results are generally 
consistent with the conclusion from Tian and others (2011), but a broader context considering other environmental variables is needed to fully appreciate the relative effect of $\mathrm{N}$ deposition on carbon sequestration in plantation forests in the future.

\section{Conclusions}

Based on our ecological simulations, we conclude that the $\mathrm{N}$ deposition generally plays a positive role in carbon sequestration in Chinese fir forests at the current mean levels ( 5 to $10 \mathrm{~kg}$ $\mathrm{ha}^{-1} \mathrm{y}^{-1}$ ) of $\mathrm{N}$ deposition in south-east China. Such $\mathrm{N}$ deposition effect could offset part of the observed long-term productivity decline, a significant problem caused by long-term mismanagement (e.g., application of short rotations and slash burning, mono-culture). However, the benefit from additional $\mathrm{N}$ deposition would be gradually diminished when the levels exceed $30 \mathrm{~kg} \mathrm{~N} \mathrm{ha}^{-1} \mathrm{y}^{-1}$ as they could cause soil $\mathrm{N}$ saturation. The total contributions of $\mathrm{N}$ deposition to $\mathrm{C}$ sequestration in the whole Chinese fir forests, south-east China are $7.4 \times 10^{6} \mathrm{Mg} \mathrm{C}_{\mathrm{year}}{ }^{-1}$ under the current deposition levels ( 5 to $10 \mathrm{~kg} \mathrm{ha}^{-1} \mathrm{y}^{-1}$ ) and could reach up to16 $\mathrm{x} 10^{6} \mathrm{Mg} \mathrm{C}$ year

${ }^{1}$ under the assumed future conditions $\left(7.5\right.$ to $\left.15 \mathrm{~kg} \mathrm{ha}^{-1} \mathrm{y}^{-1}\right)$. Because of these important effects, $\mathrm{N}$ deposition effect must be considered when evaluating forest $\mathrm{C}$ potentials under various future management and climate change scenarios.

\section{Acknowledgements}

Thanks are due to Dr. Jun Bi for creating the first version of the calibration data set and to Dr. Brad Seely for his feedback on simulating the acid rain scenarios. Guang Qin, Cheng-Yue Jie and Zan-Hong Xin helped to run the simulations. This project was funded by the British Columbia - China Innovation and Commercialization Strategic Development Program (Project \# ICSD-2007-Wei-Kimmins, British Columbia Innovation Council - BCIC, Canada). Funding 
support came also partially from the "Meiling Scholar's start-up funding” of Jiangxi Agriculture

University, State Key International Cooperation Project (grant 20073819) and The State High

Technology Funds of China (grants 2009AA122001 and 2009AA122005).

\section{Supplementary material}

Supplementary results associated with this paper can be found in the online version. 


\section{References}

Berg B, Matzner E. 1997. Effect of N deposition on decomposition of plant litter and soil organic matter in forest systems. Environmental Reviews 5: 1-25.

Bi J, Blanco JA, Kimmins JP, Ding Y, Seely B, Welham C. 2007. Yield decline in Chinese Fir plantations: A simulation investigation with implications for model complexity. Canadian Journal of Forest Research 37: 1615-1630.

Blanco JA, González E. 2010a. Exploring the sustainability of current management prescriptions for Pinus caribaea plantations in Cuba: a modelling approach. Journal of Tropical Forest Science 22(2): 139-154.

Blanco JA, González E. 2010b. The legacy of forest management in tropical forests: analysis of its long-term influence with ecosystem-level model. Forest Systems, 19: 249-262.

Blanco JA, Seely B, Welham C, Kimmins JP, Seebacher TM. 2007. Testing the performance of FORECAST, a forest ecosystem model, against 29 years of field data in a Pseudotsuga menziesii plantation. Canadian Journal of Forest Research 37: 1808-1820.

Braun S, Thomas VFD, Quiring R, Flückiger W. 2010. Does nitrogen deposition increase forest production? The role of phosphorus. Environmental Pollution 148: 2043-2052.

Chen XY, Mulder J. 2007. Indicators for nitrogen status and leaching in subtropical forest ecosystems, South China. Biogeochemistry 82: 165-180.

Chen XY, Mulder J, Wang YH, Zhao DW, Xiang RJ. 2004. Atmospheric deposition, mineralization and leaching of nitrogen in subtropical forested catchments, South China. Environmental Geochemistry and Health 26: 179-186.

Chen GS, Yan YS, Xie JS, Guo JF, Gao R, Qian W. 2005. Conversion of a natural broad-leafed evergreen forest into pure plantation forests in a subtropical area: Effects on carbon storage. Ann. For. Sci. 62: 659-668.

Churkina, G., K. Trusilova, M. Vetter and F. Dentener. 2007. Contributions of nitrogen deposition and forest regrowth to terrestrial carbon uptake. Carbon Balance and Management 2:5, doi: 10.1186/1750-0680-2-5.

Davidson, E.A., Myrold, D.D., Groffman, P.M., 1990. Denitrification in temperate forest ecosystems. In: Gessel, S.P., Lacate, D.S., Weetman, G.F., Powers, R.F. (Eds.), Sustained Productivity of Forest Soils. Forestry Publications, Faculty of Forestry, UBC, Vancouver, pp. 196-220. 
De Vries W. et al. 2008. Ecological implausible carbon response? Nature 451: E1-E3.

Dezi S, Medlyn EE, Tonon G, Magnani F. 2010. The effect of nitrogen deposition on forest carbon sequestration: a model-based analysis. Global Change Biology 16(5): 1470-1486.

Fan HB, Hong W. 2001. Estimation of dry deposition and canopy exchange in Chinese fir plantations. Forest Ecology and Management 147: 88-107.

Fang H, Mo J, Peng S, Li Z, Wang H. 2007. Cumulative effects of nitrogen additions on litter decomposition in three tropical forests in southern China. Plant and Soil 297: 233-242.

Fang J, Chen A, Peng C, Zhao S, Ci L. 2001. Changes in forest biomass carbon storage in China between 1949 and 1998. Science 292: 2320-2322.

Fang YT, Gundersen P, Mo JM, Zhu WX. 2008. Input and output of dissolved organic and inorganic nitrogen in subtropical forests of South China under high air pollution.

Biogeosciences 5: 339-352.

Fang Y, Gunderssen P, Mo J, Zhu W. 2009. Nitrogen leaching in response to increased nitrogen inputs in subtropical monsoon forests in southern China. Forest Ecology and Management 257: 332-342.

Fu X, Tian D, Xiang WH. 2006. Effects of Different Management Regimes for Cutover Areas on Soil Carbon Storage in Chinese Fir Plantations. Front. For. China 1: 38-42.

Guan LL, Zhou GY, Zhang DQ, Liu JX, Zhang QM. 2004. Twenty years of litterfall dynamics in subtropical evergreen broad-leaved forests at the Dinghushan forest ecosystem research station. Acta Phytoecologica Sinica 28, 449-456.

Hall SJ, Matson PA. 1999. Nitrogen oxide emissions after nitrogen additions in tropical forests. Nature 400: 152-155.

Huang Y, Wang SL, Feng ZW, Ouyang ZY, Wang XK, Feng ZZ. 2004. Changes in soil quality due to introduction of broad-leaf trees into clear-felled Chinese fir forest in the midsubtropics of China. Soil Use and Management 20: 418-425.

Jain A, Yang X, Kheshgi H, McGuire AD, Post W, Kicklighter D. 2009. Nitrogen attenuation of terrestrial carbon cycle response to global environmental factors. Global Biogeochemical Cycles 23, GB4028.

Kimmins JP, Mailly D, Seely B. 1999. Modelling forest ecosystem net primary production: the hybrid simulation approach used in FORECAST. Ecol. Model. 122: 195-224.

Kimmins JP, Blanco JA, Seely B, Welham C, Scoullar K. 2008. Complexity in Modeling Forest Ecosystems; How Much is Enough? Forest Ecology and Management, 256: 1646-1658. 
Kimmins JP, Blanco JA, Seely B, Welham C, Scoullar K. 2010. Forecasting Forest Futures: A Hybrid Modelling Approach to the Assessment of Sustainability of Forest Ecosystems and their Values. Earthscan. London.

Larssen T, Lydersen E, Tang D, He Y, Gao J, Liu H, Duan L, Seip HM, Vogt RD, Mulder J, Shao M, Wang Y, Shang H, Zhang X, Solberg S, Aas W, Økland T, Eilertsen O, Angell V, Liu Q, Zhao D, Xiang R, Xiao J, Luo J. 2006. Acid rain in China. Environmental Science and Technology 40: 418-425.

LeBauer DS, Treseder KK. 2008. Nitrogen limitation of net primary productivity in terrestrial ecosystems is globally distributed. Ecology 89: 371-379.

Li X. 1996. Nutrient cycling in a Chinese-fir (Cunninghamia lanceolata) stand on a poor site in Yishan, Guangxi. For. Ecol. Manage. 89: 115-123.

Li YQ, Ji JS, Chen DD. 1993. Growth responses of middle-aged Chinese fir plantation to fertilizer application. Forest Research 6: 390-396.

Li YQ, Chen DD, Ji, JS. 1992a. Growth responses of young Chinese fir to fertilizer application. In Research on Site Degradation of Timber Plantation (in Chinese). Edited by Sheng, W.T. Beijing, Science and Technology Press of China. Pp: 198-211.

Li YQ, Chen DD, Shen GD. 1992b. Growth responses of pre-matured Chinese fir plantation to fertilizer application. In Research on Site Degradation of Timber Plantation (in Chinese). Edited by Sheng, W.T. Science and Technology Press of China, Beijing. Pp: 223-239.

Lian Y, Zhang Q. 1998. Conversion of a natural broad-leafed evergreen forest into pure and mixed plantation forests in a subtropical area: effects on nutrient cycling. Can. J. For. Res. 28: $1518-1529$.

Liu X, Duan L, Mo J, Du E, Shen J, Lu X, Zhang Y, Zhou X, He C, Zhang F. 2010. Nitrogen deposition and its ecological impact in China: an overview. Environment Pollution in press. doi:10.1016/j.envpol.2010.08.002.

Lu ZH, Wu G, Ma X, Bai GX. 2002. Current situation of Chinese forestry tactics and strategy of sustainable development. Journal of Forestry Research 13: 319-322.

Lu X, Mo J, Shaofeng D. 2008. Effects of nitrogen deposition on forest biodiversity. Acta Ecologica Sinica 28: 5532-5548.

Ma X, Heal KV, Liu A, Jarvis P.G. 2007. Nutrient cycling and distribution in different-aged plantations of Chinese fir in southern China. Forest Ecology and Management 243: 61-74. 
Magnani F, et al. 2007. The human footprint in the carbon cycle of temperate and boreal forests. Nature 447: 848-852.

Matson P, Lohse KA, Hall SJ. 2002. The Globalization of Nitrogen Deposition: Consequences for Terrestrial Ecosystems. Ambio 31: 113-119.

Mo J, Li DJ, Gundersen P. 2008. Seedling growth response of two tropic tree species to nitrogen deposition in southern China. European Journal of Forest Research 127: 275-283.

Mo J, Bron S, Peng S, Kong G. 2003. Nitrogen availability in disturbed, rehabilitated and mature forests of tropical China. Forest Ecology and Management 175: 573-583.

Mo J, Brown S, Xue J, Fang Y, Li Z. 2006. Response of litter decomposition to simulated N deposition in disturbed, rehabilitated and mature forests in subtropical China. Plant and Soil 282: $135-151$.

Morris DM, Kimmins JP, Duckert DR. 1997. The use of soil organic matter as a criterion of the sustainability of forest management alternatives: a modeling approach using FORECAST. For. Ecol. Manage. 94: 61-78.

Mulder CPH, Uliassi DD, Doak DF. 2001. Physical stress and diversity-productivity relationships: the role of positive interactions. Proc. Natl Acad. Sci. 98: 6704-6708.

Nadelhoffer KJ, Emmett BA, Gundersen P, KjØnaas OJ, Koopmans CJ, Schleppi P, Tietema A, Wright RF. 1999. Nitrogen deposition makes a minor contribution to carbon sequestration in temperate forests. Nature 398: 145-148.

Ollinger SV, Aber JD, Reich PB, Freuder RJ. 2002. Interactive effects of nitrogen deposition, tropospheric ozone, elevated $\mathrm{CO}_{2}$ and land use history on the carbon dynamics of northern hardwood forests.Global Change Biology 8: 545-562.

Piao, S., J. Fang, P. Ciais, P. Peylin, Y. Huang, S. Sitch and T. Wang. 2009. The carbon balance of terrestrial ecosystems in China. Nature, 458: 1009-1014.

Richter A, Burrows JP, Granier C et al. 2005. Increase in tropospheric nitrogen dioxide over china observed from space. Nature 473: 129-132.

Sachs D, Sollins P. 1986. Potential effects of management practices on nitrogen nutrition and long-term productivity of western Hemlock Stands. For. Ecol. Manage. 17: 25-36.

Seely B, Welham C, Kimmins H. 2002. Carbon sequestration in a boreal forest ecosystem: results from the ecosystem simulation model, FORECAST. For. Ecol. Manage. 169: 123135. 
Seely B, Hawkins C, Blanco JA, Welham C, Kimmins JP. 2008. Evaluation of a mechanistic approach to mixedwood modelling. The Forestry Chronicle 84(2): 181-193.

Seely B, Welham C, Blanco JA. 2010. Towards the application of soil organic matter as an indicator of ecosystem productivity: Deriving thresholds, developing monitoring systems, and evaluating practices. Ecol. Indic. 10: 999-1008.

Sheng W, Xue X. 1992. Comparison between pure stands of Chinese fir, Fukiencypress and mixed stands of these two species in growth, structure, biomass and ecological effects. Sci. Silv. Sin. 5: 397-404 (in Chinese with English abstract).

Sheng WT. 1992. Soil degradation and its control techniques for timber plantations in China. In Research on Site Degradation of Timber Plantation (in Chinese). Edited by Sheng, W. T. Science and Technology Press of China, Beijing. Pp 1-7.

Smith WH. 1990. Air pollution and forests: interaction between air contaminants and forest ecosystems $2^{\text {nd }}$ ed. Springer-Verlag, New York, NY. 617 pp.

Struwe S, Kjøller A. 1991. Denitrification in wet forest soil systems in situ and in slurry experiments. For. Ecol. Manage. 44: 41-52

Tian H, Melillo J, Lu C, Kicklighter D, Liu M, Ren W, Xu X, Chen G, Zhang C, Pan S, Liu J, Running S. 2011. China's terrestrial carbon balance: contributions from multiple global change factors. Global Biogeochemical Cycles, 25, GB1007, doi: 10.1029/2010GB003838.

Thomas RQ, Canham CD, Weathers KC, Goodale CL. 2010. Increased tree carbon storage in response to nitrogen deposition in the US. Nature Geoscience 3: 13-17.

Townsend AR, Braswell BH, Holland EA, Penner JE. 1996. Spatial and temporal patterns in potential terrestrial carbon storage resulting from deposition of fossil fuel derived nitrogen, Ecol. Appl. 6(3): 806-814.

Ulrich B. 1991. An ecosystem approach to soil acifification. Pp. 28-79 in: Ukich, B. and Sumner, M.E. (ed.) Soil Acidity, Springer-Verlag, Berlin.

Wang S, Chen JM, Ju WM, Feng X, Chen M, Chen P, Yu G. 2007. Carbon sinks and sources in China $^{1}$ s forests during 1901-2001. Journal of Environmental Management 85: 524-537.

Wang JR, Comeau P, Kimmins JP. 1995. Simulation of mixedwood management of aspen and white spruce in Northeastern British Columbia. Water, Air Soil Pollut. 82: 171-178.

Wei X, Liu W, Waterhouse M, Armleder M. 2000. Simulation on impacts of different management strategies on long-term site productivity in lodgepole pine forests of the central interior of British Columbia. For. Ecol. Manage. 133: 217-229. 
Wei X, Kimmins JP, Zhou G. 2003. Disturbance and the sustainability of long-term site productivity in lodgepole pine forests in the central interior of British Columbia - an ecosystem modeling approach. Ecol. Model. 164: 239-256.

Wu ZL, (ed). 1984. Chinese-fir (in Chinese). China Forestry Publishing House. Beijing. 583 pp.

Wu ZY, Raven PH. (eds). 1999. Flora of China, 4: 54-61. Science press, Beijing, PRC.

Yang X, Richardson TK, Jain AK. 2010. Contributions of secondary forest and nitrogen dynamics to terrestrial carbon uptake. Biogeosciences 7: 3041-3050.

Yu XT. 1988. Research on Chinese-fir in China. J. Fujian College For. 8: 203-220 (in Chinese with English abstract).

Yu XT. (ed). 1997. Silviculture of Chinese Fir (in Chinese). Science and Technology Press of Fujian, Fuzhou, Fujian Province.

Yu XT. 1999. Chinese fir (book chapter: page 1-29-1049, in Chinese). In Chinese Forests. Edited by Chinese Forests Editorial Committee. China Forestry Publishing House. Beijing. 1161 pp.

Zaehle S, Friend AD, Friedlingstein P, Dentener F, Peylin P, Schulz M. 2010. Carbon and nitrogen cycle dynamics in the O-CN land surface model: 2. Role of the nitrogen cycle in the historical terrestrial carbon balance. Global Biogeochemical Cycles 24, GB1006.

Zhao S, Liu S, Yin R, Li Z, Deng Y, Tan K, Deng X, Rothstein D, Qi J. 2010. Quantifying terrestrial ecosystem carbon dynamics in the Jinsha watershed, upper Yangtze, China from 1975 to 2000. Environmental Management 45: 466-475.

Zhang XQ, Kirschbaum MUF, Hou Z, Guo Z. 2004. Carbon stock changes in successive rotations of Chinese fir (Cunninghamia lanceolata (lamb) hook) plantations. Forest Ecology and Management 202: 131-147.

Zhang YM, Zhou GY, Wen DZ, Zhang DQ, Zhang QM. 2002. Biomass dynamics of the Castanopsis chinensis-Schima superba-Cryptocarya concinna community of monsoon evergreen broad-leaved forest in Dinghushan Reserve. Trop. Subtrop. For. Ecosys. 9: 10-17.

Zhong AL, Hsiung WY. 1993. Evaluation and diagnosis of tree nutritional status in Chinese-fir (Cunninghamia lanceolata (Lamb) Hook) plantations, Jiangxi, China. For. Ecol. Manage. 62: 245-270. 


\section{Tables}

Table 1. Initial conditions for simulations (values at year zero) (Belowground C includes the carbon in litter, humus and dead roots)

\begin{tabular}{lrr}
\hline Variable & Poor site & \multicolumn{2}{c}{ Rich } \\
& \multicolumn{2}{c}{ site } \\
\hline Site index (top height m at 50 years) & 18 & 26 \\
Forest floor mass $\left(\mathrm{Mg} \mathrm{ha}^{-1}\right)$ & 24.1 & 49.3 \\
Humus mass $\left(\mathrm{Mg} \mathrm{ha}^{-1}\right)$ & 59.7 & 73.1 \\
Belowground C $\left(\mathrm{Mg} \mathrm{ha}^{-1}\right)$ & 37.7 & 55.1 \\
Available soil $\mathrm{N}\left(\mathrm{kg} \mathrm{ha}^{-1} \mathrm{yr}^{-1}\right)$ & 139.2 & 202.6 \\
\hline
\end{tabular}


Table 2. Summary of graphical outputs (see Figures 2-5 and Supplementary material figures) of long-term effect trends of N

deposition levels (in $\mathrm{kg} \mathrm{N} \mathrm{ha}^{-1} \mathrm{y}^{-1}$ ) on several ecosystem variables at two planted forests in two different site qualities.

\begin{tabular}{|c|c|c|c|c|c|c|c|c|c|c|c|c|c|c|}
\hline \multirow{2}{*}{$\begin{array}{l}\mathrm{N} \text { deposition level } \\
\text { Site }\end{array}$} & \multicolumn{2}{|c|}{1} & \multicolumn{2}{|c|}{5} & \multicolumn{2}{|c|}{10} & \multicolumn{2}{|c|}{20} & \multicolumn{2}{|c|}{30} & \multicolumn{2}{|c|}{40} & \multicolumn{2}{|c|}{50} \\
\hline & Poor & Rich & Poor & Rich & Poor & Rich & Poor & Rich & Poor & Rich & Poor & Rich & Poor & Rich \\
\hline Site quality & ע & 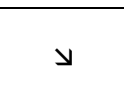 & $=$ & ע & $\begin{array}{c}15,50 \pi \\
30=\end{array}$ & $\begin{array}{c}15,30 y \\
50=\end{array}$ & $\pi$ & $\begin{array}{l}15 \searrow \\
30= \\
50 \pi\end{array}$ & $\pi$ & $\begin{array}{c}15 \text { ע } 30,50 \pi \\
30,\end{array}$ & $\pi$ & $\pi$ & $\pi$ & $\pi$ \\
\hline Merchantable volume & $=$ & $=$ & $\begin{array}{c}15= \\
30,50 \pi\end{array}$ & $=$ & $\begin{array}{c}15,30= \\
50 \pi\end{array}$ & $\begin{array}{c}15= \\
30,50 \pi\end{array}$ & $\begin{array}{c}15= \\
30,50 \pi\end{array}$ & $\begin{array}{c}15= \\
30,50 \pi\end{array}$ & $\pi$ & $\pi$ & $\pi$ & $\pi$ & $\pi$ & $\pi$ \\
\hline Aboveground $\mathrm{C}$ & ע & ע & $\begin{array}{c}15,30 \text { ل } 50=\end{array}$ & $\begin{array}{c}15,30 \text { ل } 50=\end{array}$ & $\begin{array}{c}15= \\
30,50 \pi\end{array}$ & $\begin{array}{c}15,30 \pi \\
50 \pi\end{array}$ & $\pi$ & $\pi$ & $\pi$ & $\pi$ & $\pi$ & $\pi$ & $\pi$ & $\pi$ \\
\hline Root C & $y$ & $y$ & $\begin{array}{c}15,30 \text { ل } 50=\end{array}$ & $\begin{array}{c}15,30 \text { ل } 50=\end{array}$ & $\begin{array}{c}15= \\
30,50 \pi\end{array}$ & $\begin{array}{c}15,30 \pi \\
50 \pi\end{array}$ & $\pi$ & $\pi$ & $\pi$ & $\pi$ & $\pi$ & $\pi$ & $\pi$ & $\pi$ \\
\hline Forest soil C & ע & ע & $\begin{array}{l}15 \text { ע } \\
30= \\
50 \pi\end{array}$ & $\begin{array}{c}15,30 \searrow \\
50=\end{array}$ & $\begin{array}{c}15= \\
30,50 \pi\end{array}$ & $\begin{array}{l}15 \text { У } \\
30= \\
50 \pi\end{array}$ & $\pi$ & $\begin{array}{c}15= \\
30,50 \pi\end{array}$ & $\pi$ & $\pi$ & $\pi$ & $\pi$ & $\pi$ & $\pi$ \\
\hline Humus C & 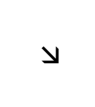 & $\begin{array}{c}15,30 \text { ע } 50 \\
\end{array}$ & $\begin{array}{l}15 \text { ע } \\
30= \\
50 \pi\end{array}$ & $\begin{array}{c}15,30 \text { ע } 50 \pi \\
\end{array}$ & $\begin{array}{c}15 \text { ע } 30,50 \pi \\
30,\end{array}$ & $\begin{array}{c}15 \text { ע } 30,50 \pi \\
30,\end{array}$ & $\pi$ & $\begin{array}{c}15= \\
30,50 \pi\end{array}$ & $\pi$ & $\pi$ & $\pi$ & $\pi$ & $\pi$ & $\pi$ \\
\hline Belowground C & لا & $\begin{array}{c}15,30 \text { ע } \\
50=\end{array}$ & $\begin{array}{l}15 y \\
30= \\
50 \pi\end{array}$ & $\begin{array}{l}15 y \\
30= \\
50 \pi\end{array}$ & $\begin{array}{c}15 \text { ע } 30,50 \\
30,\end{array}$ & $\begin{array}{c}15 \text { ע } 15,50 \pi \\
30,50\end{array}$ & $\pi$ & $\begin{array}{c}15= \\
30,50 \pi\end{array}$ & $\pi$ & $\pi$ & $\pi$ & $\pi$ & $\pi$ & $\pi$ \\
\hline Total ecosystem C & ע & ע & $\begin{array}{c}15,30 \text { ע } \\
50=\end{array}$ & $\begin{array}{c}15,30 y \\
50=\end{array}$ & $\begin{array}{c}15 \text { ע } 30,50 \\
30\end{array}$ & $\begin{array}{l}15 y \\
30= \\
50 \pi\end{array}$ & $\begin{array}{c}15= \\
30,50 \pi\end{array}$ & $\begin{array}{c}15= \\
30,50 \pi\end{array}$ & $\pi$ & $\pi$ & $\pi$ & $\pi$ & $\pi$ & $\pi$ \\
\hline Deposited N Efficiency & $y$ & 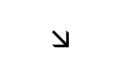 & $y$ & $\begin{array}{c}15,30 y \\
50=\end{array}$ & $=$ & $=$ & $=$ & $=$ & $=$ & $=$ & $=$ & $=$ & $=$ & $=$ \\
\hline Leached N & ע & ע & $\begin{array}{c}15 \text { ע } \\
30,50=\end{array}$ & $\begin{array}{c}15 \text { ע } \\
30,50=\end{array}$ & $\begin{array}{l}15 \text { ע } \\
30= \\
50 \pi\end{array}$ & $\begin{array}{c}15 \text { ע } \\
30,50 \pi\end{array}$ & $\begin{array}{c}15= \\
30,50\end{array}$ & $\begin{array}{c}15= \\
30,50 \pi\end{array}$ & $\pi$ & $\pi$ & $\pi$ & $\pi$ & $\pi$ & $\pi$ \\
\hline Available soil $\mathrm{N}$ & ע & $y$ & ע & $y$ & $\begin{array}{c}15,30 \pi \\
50 \pi\end{array}$ & $\begin{array}{c}15,30 y \\
50=\end{array}$ & $\begin{array}{c}15 \text { ע } 30,50 \\
30,\end{array}$ & $\begin{array}{c}15 \text { ע } 30,50 \pi \\
30,\end{array}$ & $\begin{array}{c}15 y \\
30,50 \\
\pi\end{array}$ & $\begin{array}{c}15 \text { ע } 30,50 \pi \\
30,\end{array}$ & $\pi$ & $\begin{array}{c}15 \text { ע } 30,50 \pi \\
30\end{array}$ & $\pi$ & $\pi$ \\
\hline Foliar N & ل & ע & $\begin{array}{c}15 y \\
30,50=\end{array}$ & $\begin{array}{c}15,30 \text { ע } 50 \pi \\
\text { עo }\end{array}$ & $\begin{array}{c}15= \\
30,50 \pi\end{array}$ & $\begin{array}{l}15 y \\
30= \\
50 \pi\end{array}$ & $\pi$ & $\begin{array}{c}15= \\
30,50 \pi\end{array}$ & $\pi$ & $\pi$ & $\pi$ & $\pi$ & $\pi$ & $\pi$ \\
\hline Nutrient Use Efficiency & $\pi$ & $y$ & $\pi$ & $\begin{array}{c}15,30 \text { ע } \\
50=\end{array}$ & $\pi$ & $\begin{array}{c}15,30 y= \\
50=\end{array}$ & $\pi$ & $\begin{array}{l}15 \text { ע } \\
30= \\
50 \pi\end{array}$ & $\pi$ & $\begin{array}{c}15= \\
30,50\end{array}$ & $\pi$ & $\pi$ & $\pi$ & $\pi$ \\
\hline Net Primary Production & ע & $y$ & $\begin{array}{l}15 \searrow \\
30= \\
50 \pi\end{array}$ & $\begin{array}{c}15,30 \text { ل } \\
50=\end{array}$ & $\begin{array}{c}15= \\
30,50 \pi\end{array}$ & $\begin{array}{l}15 \text { ע } \\
30= \\
50 \pi\end{array}$ & $\pi$ & $\begin{array}{c}15 \text { ע } 15 \\
30,50\end{array}$ & $\pi$ & $\pi$ & $\pi$ & $\pi$ & $\pi$ & $\pi$ \\
\hline
\end{tabular}


Table 3. Annual increase in sequestered carbon in Chinese fir forests under current and future $\mathrm{N}$ deposition rates, compared to preindustrial levels $\left(1 \mathrm{~kg} \mathrm{~N} \mathrm{ha}^{-1} \mathrm{y}^{-1}\right)$.

\begin{tabular}{|c|c|c|c|c|c|c|c|c|}
\hline \multirow{4}{*}{$\begin{array}{l}\text { N deposition rate } \\
\qquad \mathrm{Kg} \mathrm{N} \mathrm{ha}^{-1} \mathrm{y}^{-1}\end{array}$} & \multirow{2}{*}{\multicolumn{2}{|c|}{$\begin{array}{l}\text { Average increase in } \mathrm{C}^{\mathrm{a}} \\
\qquad \mathrm{Mg} \mathrm{ha} \mathrm{y}^{-1} \mathrm{y}^{-1}\end{array}$}} & \multirow{2}{*}{\multicolumn{2}{|c|}{$\begin{array}{c}\text { Chinese fir area } \\
\text { ha }\end{array}$}} & \multirow{2}{*}{\multicolumn{4}{|c|}{$\begin{array}{l}\text { Increase in sequestered Carbon } \\
\qquad 10^{3} \mathrm{Mg} \mathrm{y}^{-1}\end{array}$}} \\
\hline & & & & & & & & \\
\hline & \multirow{2}{*}{ Aboveground } & \multirow{2}{*}{$\begin{array}{c}\text { Total } \\
\text { Ecosystem }\end{array}$} & \multirow[t]{2}{*}{2008} & \multirow[t]{2}{*}{ Future $^{b}$} & \multicolumn{2}{|c|}{2008} & \multicolumn{2}{|c|}{ Future $^{b}$} \\
\hline & & & & & Aboveground & $\begin{array}{c}\text { Total } \\
\text { Ecosystem }\end{array}$ & Aboveground & $\begin{array}{c}\text { Total } \\
\text { Ecosystem }\end{array}$ \\
\hline $1-5$ & 0.00 & 0.00 & 0 & 0 & 0 & 0 & 0 & 0 \\
\hline $5-10$ & 0.35 & 1.04 & 7004400 & 0 & 2474 & 7312 & 0 & 0 \\
\hline $10-20$ & 0.86 & 2.27 & 31200 & 7004400 & 26 & 70 & 6051 & 15897 \\
\hline$>20$ & 2.25 & 5.42 & 0 & 31200 & 0 & 0 & 70 & 126 \\
\hline TOTAL & - & - & 7035600 & 7035600 & 2501 & 7383 & 6121 & 16024 \\
\hline
\end{tabular}

${ }^{a}$ Average of different site qualities, different $\mathrm{N}$ deposition rates and different rotation lengths.

${ }^{\mathrm{b}}$ The future scenario assumes that the current areas under different $\mathrm{N}$ deposition rates will sift to one category of $\mathrm{N}$ deposition rate higher. 


\section{Figure legends}

Figure 1. N deposition levels in south-east China in 2008 (colour scale, data from Zhejiang Agriculture and Forestry University). Stripped area indicates the provinces that are the main distribution area of Chinese fir (based on the work by Yu [1999])

Figure 2. Model projections of total aboveground $\mathrm{C}$ at the end of each rotation for two different sites under six different $\mathrm{N}$ deposition levels.

Figure 3. Model projections of total ecosystem carbon (aboveground + belowground) at the end of each rotation for two different sites under six different $\mathrm{N}$ deposition levels.

Figure 4. Deposited N efficiency (total ecosystem C / total N deposited) at the end of each rotation for two different sites under six different $\mathrm{N}$ deposition levels.

Figure 5. Total accumulated leaching losses and total accumulated $\mathrm{N}$ retained in the ecosystem (total deposition - total leaching losses) at the end of 300 years for two different sites under six different $\mathrm{N}$ deposition levels. 


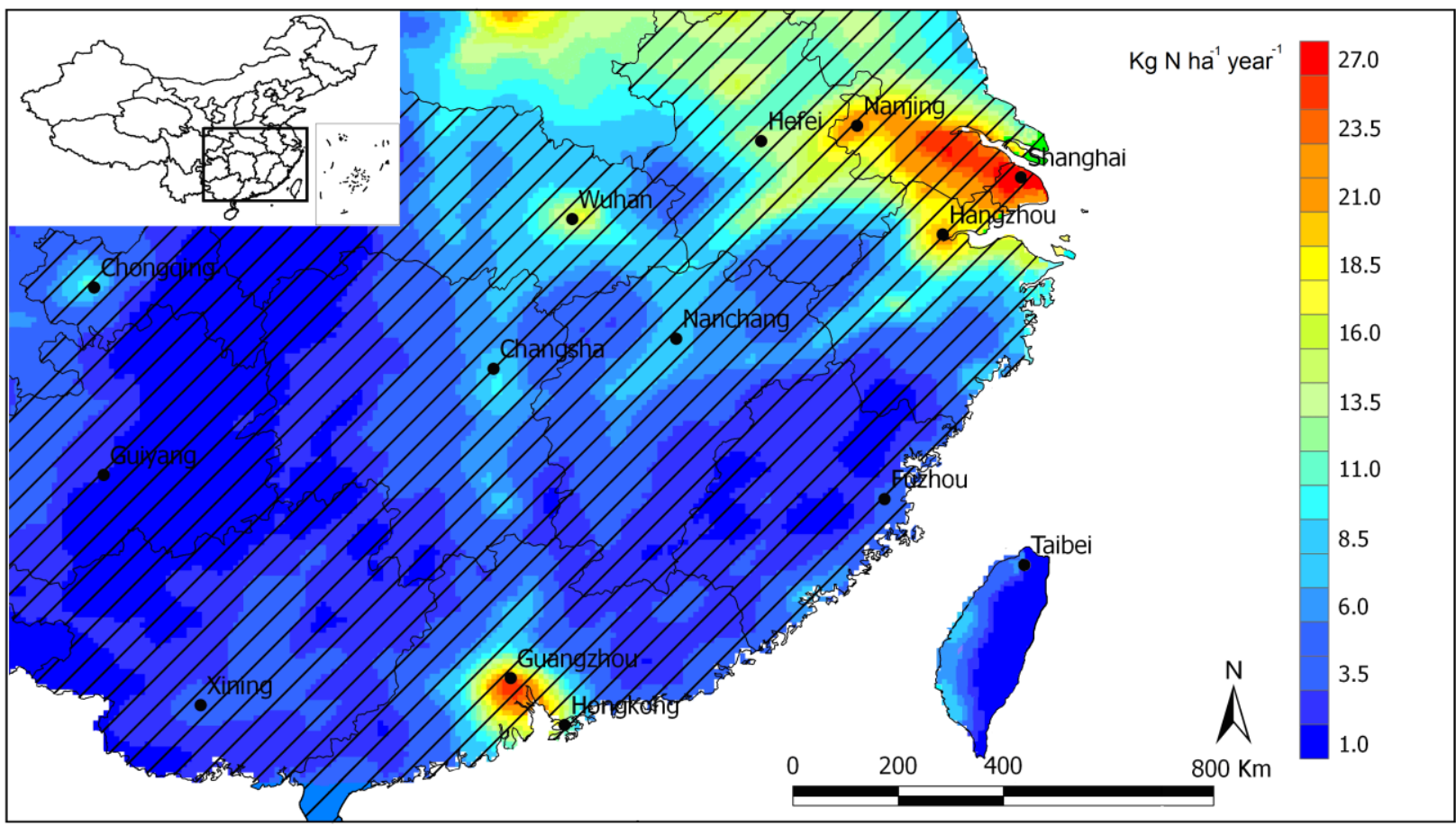

Figure 1. 


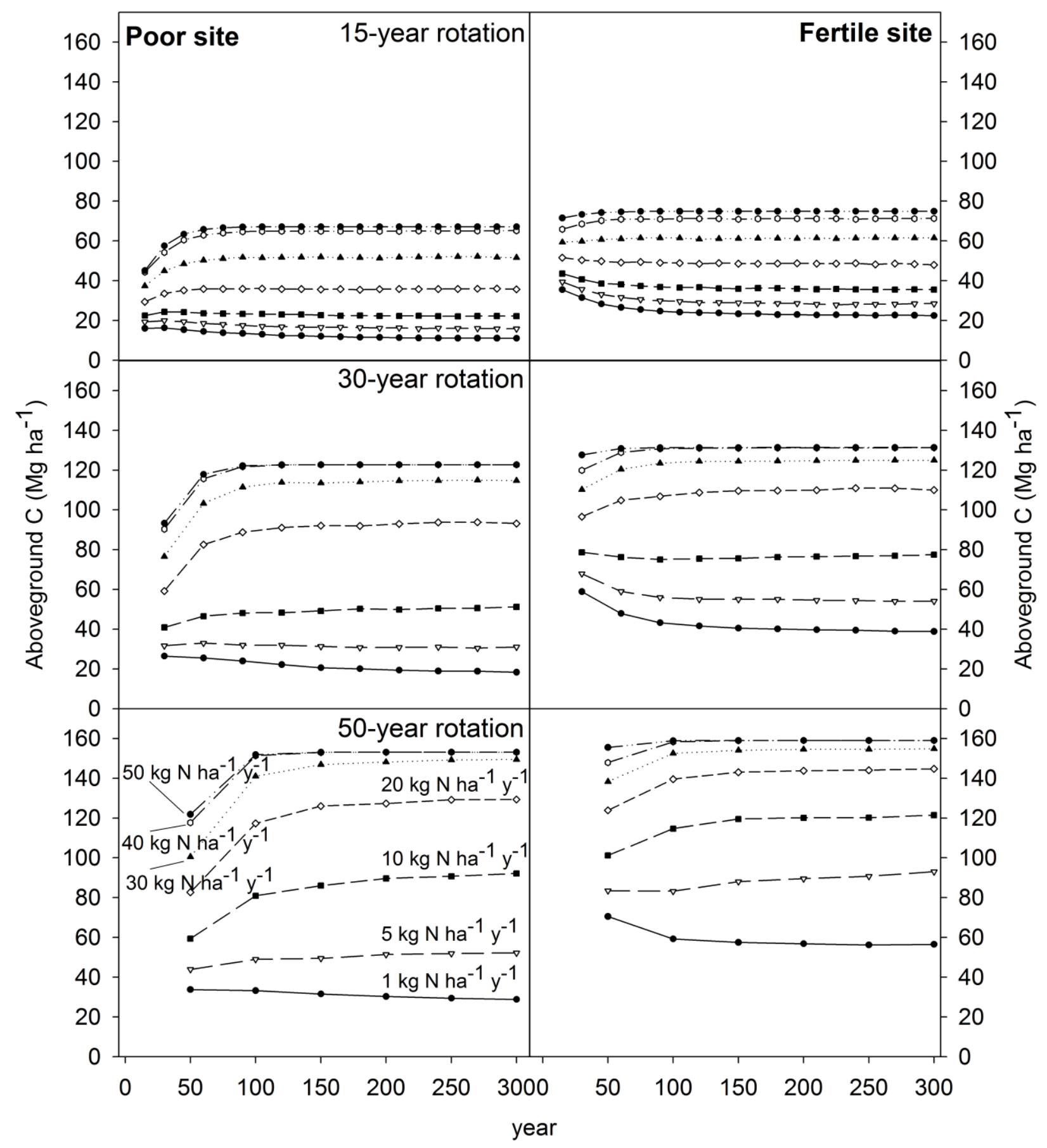

Figure 2. 


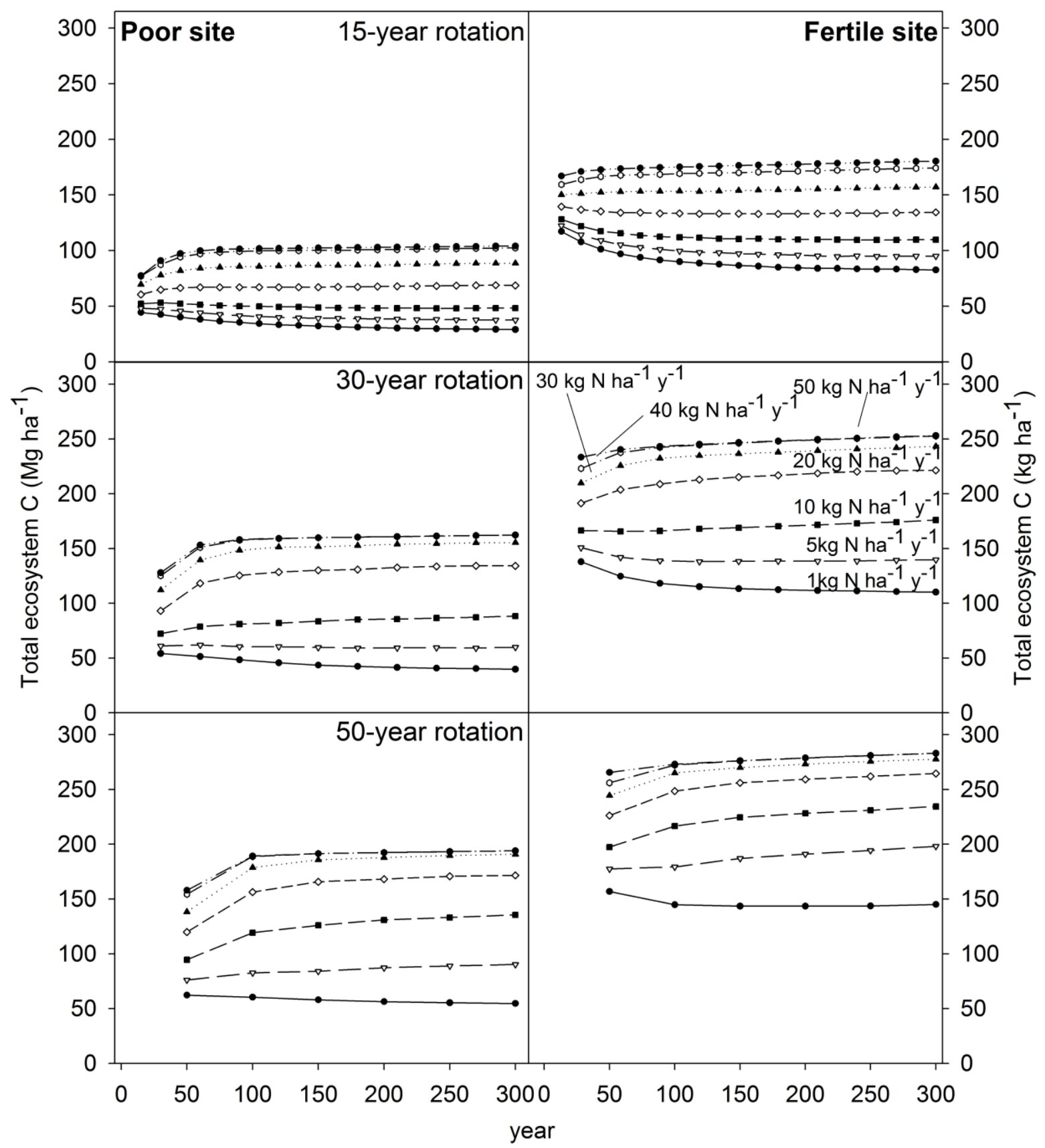

Figure 3. 


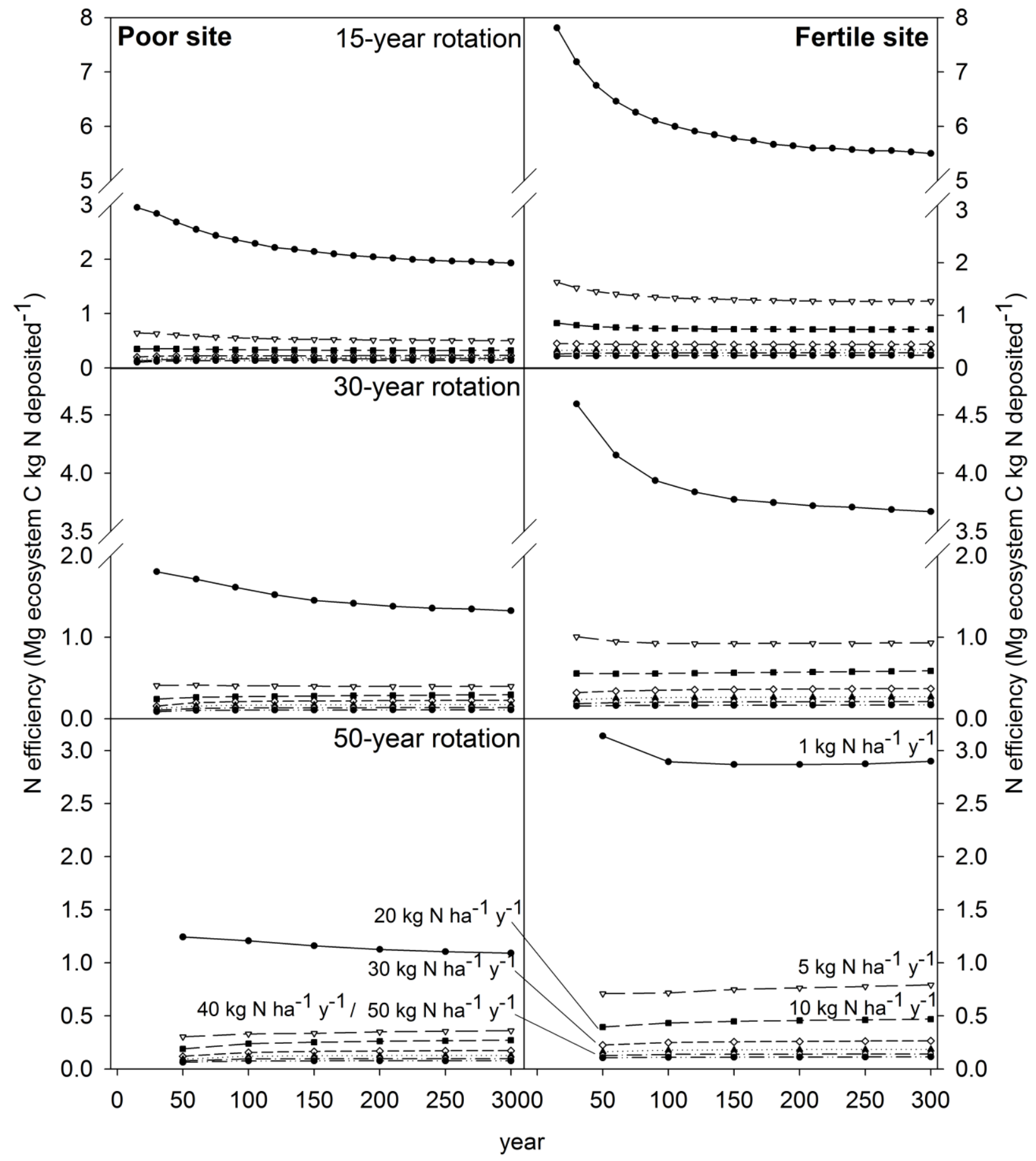

Figure 4. 


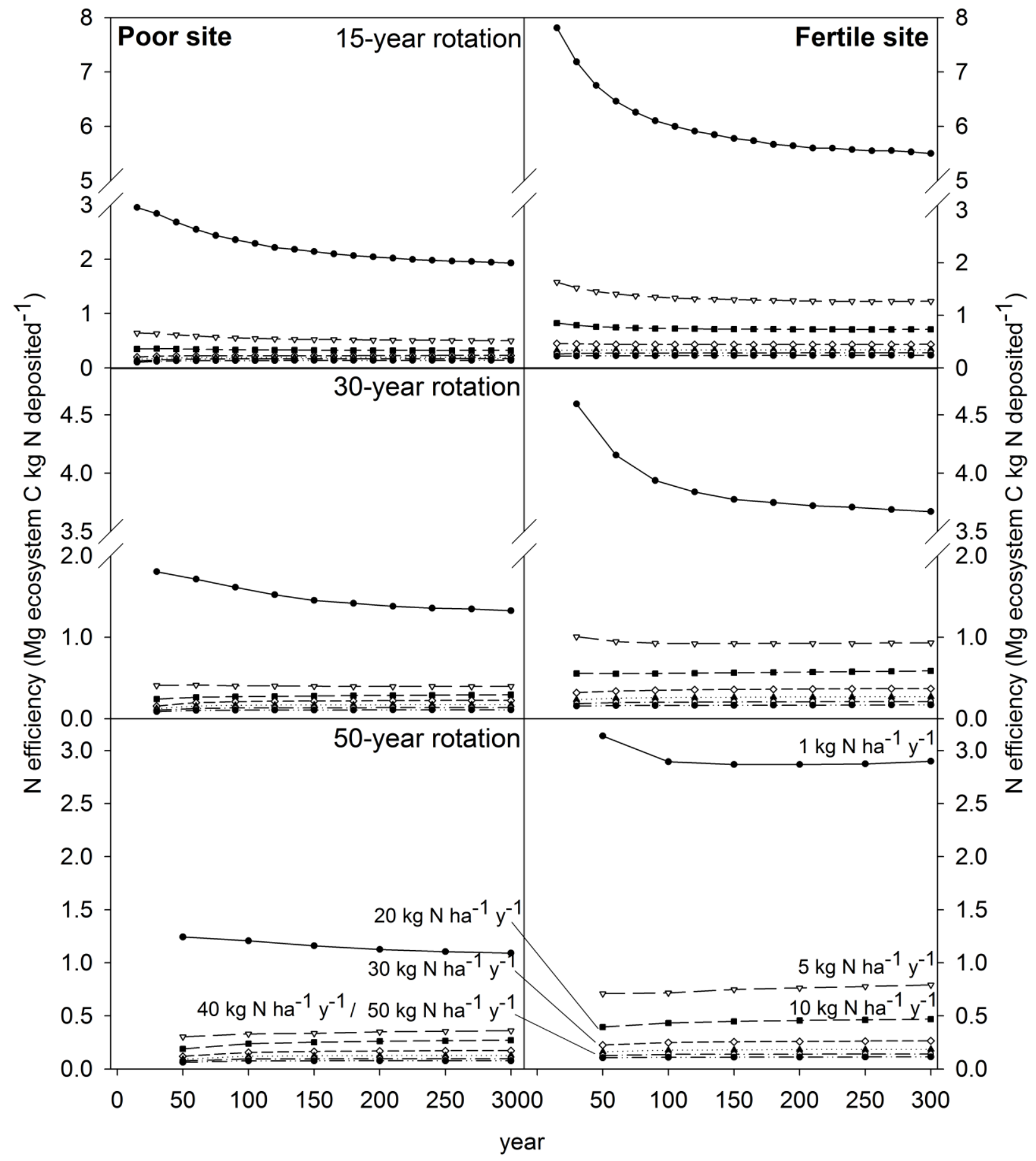

Figure 5. 


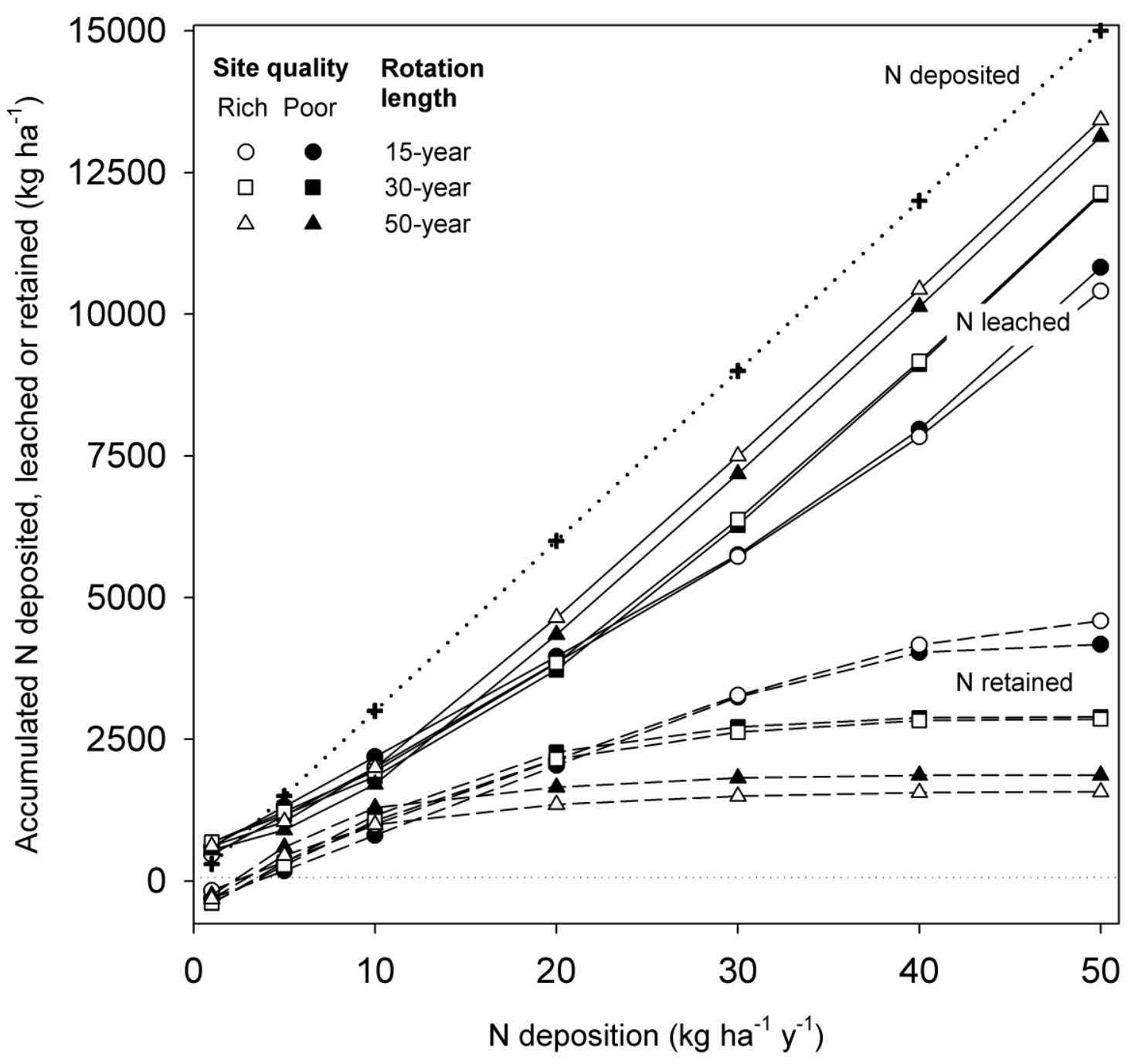

Figure 6. 